\title{
特集：野生動物保全のための種保存計画における現状と課題
}

第 10 回日本野生動物医学会大会 ワークショップ 2004 年 9 月 17 日 東京大学

希少動物の種の保存を目的とした保全繁殖技術

\author{
楠 比呂志 \\ 神戸大学農学部附属食資源教育研究センター ₹ 675-2103 兵庫県加西市敦野町 1348
}

\section{Reproductive Technologies for Species Conservation}

Hiroshi KUSUNOKI

Food and Bioresources Research Institute, Kobe University, Kasai, Hyogo 675-2103, Japan

\begin{abstract}
The world is now in the midst of the fastest mass extinction of wildlife. The author believes that preserving the threatened species is the urgency of the mankind. In the promotion of the ex-situ conservation, artificial reproductive technologies, such as artificial insemination, in vitro fertilization including intracytoplasmic sperm injection, embryo transfer, cryopreservation of germplasm, in vitro spermatogenesis, nuclear transfer and possibly cloning, become useful tools. In this review, I describe various techniques for collecting the germplasm from wild animals (artificial vagina method, manual stimulation, electroejaculation, postmortem recovery, etc.). Finally, the future of our planet depends on human beings and animals learning to live together.
\end{abstract}

Key words : artificial reproductive technology, embryo, ex-situ conservation, oocyte, sperm

Jpn.J.Zoo. Wildl.Med. 10(1) : 1-12, 2005

\section{はじめに}

家畜における人工繁殖技術は, 消費者の食生活の高度化と二 ーズの多様化，また様々な発生工学技術の開発を背景として飛 躍的に発展を遂げ，生物の究極の規格化ともいえるクローン家 畜の作出 [1] に成功するまでに至っている。また,これらの 技術の一部は, ヒトの不妊症の治療にも応用され, 子宝に恵ま れない夫婦の福音となっている。

一方，現在，過去に類をみない速度で，大量の野生生物 が絶滅の淵に追いやられている。2003 IUCN Red List of Threatened Species [2] によれば, その数は, 脊椎動物, 無 脊椎動物, 植物など併せて 12,259 種であるという。Raup と Stanley [3] は, この大量絶滅の原因の 99\%が, 地球温暖化 を始めとする人間活動に起因する環境破壊であると指摘してい る。また, Thomasら［4]によれば，地球温暖化がこのまま 進むと，2050 年までに陸上の動植物の 15 ～37\%，すなわち 百万種以上が絶滅するという。まさにこれらの種の保存は, 我々 人類の急務である。

保全繁殖技術 (Reproductive Technologies for Species Conservation）とは, 絶滅の危機に晒された希少動物の種の保 存を目的とした繁殖技術を指し、生息地外保全を進める上で必
要不可欠な技術である。

\section{生息地外保全（ex-situ Conservation）と保全繁殖技術}

いうまでもなく，野生動物の種の保存は，本来の生息地で行 うのが本道である。しかし, 生息地が回復不能にまで破壊また は污染されていたり，たとえ回復可能でもそれまでに動物が絶 滅する危険性が高い場合，種の保存は生息地外の自然保護区や 動物園・水族館などで緊急避難的に行うしか手がなく，その必 然性については, 1993 年末に我が国でも発効した Convention on Biological Diversity [5] にも謳われている。

また, IUDZG-The World Zoo Organization \& The Captive Breeding Specialist Group of IUCN/SSC (IUDZG-WZO \& CBSG/ SSC）も，1993年に発表した The World Zoo Conservation Strategy [6] のなかで, 生息地外保全の基地および研究施 設としての動物園・水族館の将来構想を明示している。こ のStrategyに世界の動物園の総数は 1,165 施設と記載さ れており，米国ミネソタ州 EaganにCentral Office を置く International Species Information System（ISIS）のデーター ベース [7] に登録されている飼育（動物園）動物の総数は, 南極を除く 6 大陸の 72 ケ国 600 以上の施設で約 1 万種 200 万頭以上とあり，世界中の動物園が協力すれば，全ては無理で 
楠比呂志

も，かなりの数の動物種について，種を維持できるだけの最少 個体数を緊急避難させることは可能かもしれない。しかし現実 には，例え一つの種といえども，生息地の環境が回復して野牛 復帰が问能となるまで, 限られた飼育下スペースで, 遺伝的多 様性を維持しながら累代繁殖し続けるのは，至難の業である。

牛息地外で種の保存を行う場合でも，必要以上にヒトの手 を加えないことが望ましく，繁殖も自然の営みによってなされ るべきである。しかし，飼育下では，環境不良や栄養障害，ま た遺伝的欠䍀などを主因とする繁殖障害（図1，2）が生じや すいことが報告されている $[8,9]$ 。これらの治療においては, 飼老環境の改善や計画的な遺伝管理などを図ることが第一であ ることはいうまでもなく, 動物園・水族館では日夜その努力が 続けられている。しかし，それでも治癒が困難な場合には，ヒ トの不娃症治療と同じように，人工授精や体外受精・肧移植 といった生殖介助技術の適用が必要となる。また, 個体数や 性比に修正林難な著しい減少や偏りが生じた場合には，絶滅の 心配がない近緣の動物の甘体を利用した異種間での肧移植も有

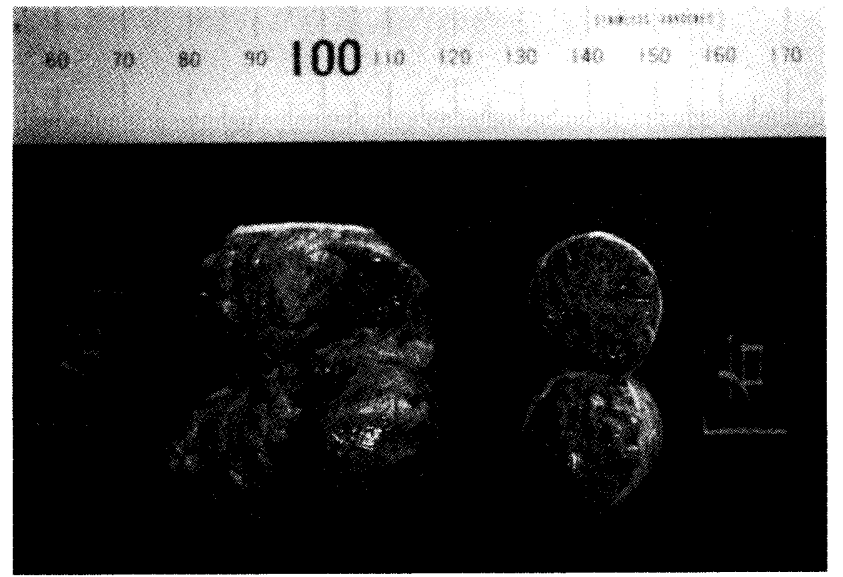

図 1 ニシローランドゴリラの精巣（左）に見られた腫瘍



図 2 ニシローランドゴリラの卵巣（右）に見られた囊腫
用であり，これまでに，野牛のバンテンやガウル，アルメニア ムフロン，スパニッシュアイベッタス，グアナコ，モウコノウ マ, グラントシマウマ抢よびステップヤマネコやリビアヤマネ コの肧を，それぞれウシ，ヒツジ，ヤギ，リヤマ，ポニー，ロ バ执よ゙イエネコの子宮などに移植して産子が得られている [10-19]。

さらに，動物を生体ではなく，生殖子（配偶子や胀）の状態 で保存すれば, 飼育スペースの問題はかなり解消でき, 䬲青に かかる莫大な経費も相当軽減できる。また, 遺伝子をそのまま の状態で, 野生復帰時まで長期間保持することも谷易である。 米国 San Diego Zoo の Center for Reproduction of Endangered Species (CRES) の Frozen Zooでは, 1980 年から牛殖子の収 集を始め,これまでに 280 種 1,040 個体分を保存したという [20。また我が国では，筆者らが中心となって設立した希少 動物人丁繁殖研究会のZ Zoo Bankが, 1992 年から収集を始め, これまでに 128 種 338 個体の希少動物の配偶子を保存してい る(表 1)。

このように, 各種の生殖介助技術や生殖子の保存技術などは, 膨大な数に上る希少動物の種の保存を進めて行く上で, 必䘫不 可欠な手段である。しかし，現在確立しているこれらの技術の 大部分は, 実験動物や家畜, またヒトなどを対象として開発さ れたもので，繁殖生理や習性の異なる野生動物にはそのままで は適用が難しく、特別な工夫や大幅な修正が必琶なものも多い。

野生動物の繁殖生理のうち, 雌の排卵 (発情) や受精・着) 休 (娃 娠）などの機序，また卵母細胞や肧の性状については，特に体 内受精型のものでは, 解明されている種の方がまだ压倒的に少 ない。一方, 精子の特性については, 1677 年のヒト精子の発 見以来 [21], 数多くの研究者が, 有性生殖における配偶一゚ と しての科学的なあるいは神秘的な興味から，またその形態他の 種毎の多様性に基づく比較生物学的な見地から, 腔晹動物のよ うな下等なものから高等な哺乳動物に至るまで, 相当数の動物 種について観祭と記録を行っており, かなりの情報が蓄積され ている $[22,23]$ 。

野生動物の人工繁殖に関する研究は, 当初, 未家音化動物の 生物資源としての開発・利用を主目的として，1970 年代に炊 米で始まり [24], その後, 動物園や水族館でも, 種の保存を 念頭に置いて取り組まれるようになった $[25,26]$ 。特に米[E] では，専門の研究スタッフと設備を備えた National Zoological Park の Conservation and Research Center や前述の CRES, Cincinnati Zoo and Botanical Garden $\omega$ Center for Research of Endangered Wildlife などが先導役となって, 飼育下個体のみ ならず野生個体をも対象として活発な研究が続けられ, 阹上: で最大の動物であるゾウの人工授精を成功させるまでに至って いる $[27,28]$ 。一方我が国では，欧米に遅れること約 20 年, 
1993 年に希少動物人工繁殖研究会が設立され，保全繁殖技術 に関する組織的・体系的な研究が本格的に始まった [29]。

\section{保全繁殖技術の実際 一生殖子の採取一}

|:述のように，保全繁殖技術の多くは，実験動物や家畜，ヒ トなどで開発された技術に工夫や修正を加えて，動物園動物や 野生動物に適合させたものである。人工繁殖の材料となる生殖 子の採取方法についても，同様のことがえる。

\section{1. 生体からの採取}

従順な家畜では十分な訓練が可能なため，ウシ，ヒツジ，ヤ ギおよびウマでは，精子（精液）の採取に人工腟法 [30］が 日常的に使用されている。この方法では, 保定した台雌（雄で もよい）や擬牡台に雄を乗駕させ，勃起した陰茎を腟の温感と 触感を似せた筒状の器具内に誘導して射精させる。

人工腟のような器具を用いずにマッサージで射精を促す手技 もあり，ブタでは，雄を擬牡台に乗駕させ，勃起した螺旋状の 陰芠の先端を掌で包多込むようにして掴み，軽く圧迫して射精 を促す方法(手掌圧迫法または手圧法)が多用されている $[31]$ 。 イヌも，陰茎の基部をマッサージする方法で容易に精液が採取 できる $[32,33]$ ままた，ニワトリやシチメンチョウなどの家 禽では，腹部や背部，大腿部などをマッサージする方法（腹部 マッサージ法) が日常的に使われている [34]。実際に使われ ることは少ないが，ウシでは，直腸検査の要領で，精管膨大部 をマッサージして射精を促す方法もある [35]。

野生動物でもあまりストレスを与えずに安全に保定ができれ ば，また十分に馴致のできた飼育下（動物園）個体では，人工 胵法やマッサージ法で精液を採取することが可能である。人工 膣法は，様々な草食獣 $[8,36]$ （図 3 ）やチンパンジー $[37$, 38]，チーター[39] などで実施されて抢り，家畜用の市販の 器具が対象動物の陰茎のサイズに合わない場合には，手作りの ものが用いられている。陰茎マッサージ法については，キッネ [40] や才才力ミ[41] などのイヌ科動物以外にも，レッサー パンダ [42（図 4）やバンドウイルカなどの小型鯨類 [43] で行われている。また精管マッサージ法は，ゾウ [44-45] に 応用されている。

腹部マッサージ法は，キジ [46-48]，ツル [49-51]，タカ やハヤブサ [52-57]，カナダガン [58]，インコ [59-61]（図 5 ）抢よびペンギン (楠未発表) などの様々な鳥類において, それぞれに適した保定方法のもとで実施されており，現生の鳥 類の中で最大のダチョウでも，精管乳頭をマッサージして精液 が採取できるという [62]。な扔タ力では，性的刷り込みを利 用すれば，訓練で，自発的に射精させることも可能である $[57$ $63]$ 。

魚類では，精液量が極めて少ないドジョウなどの例外を除い

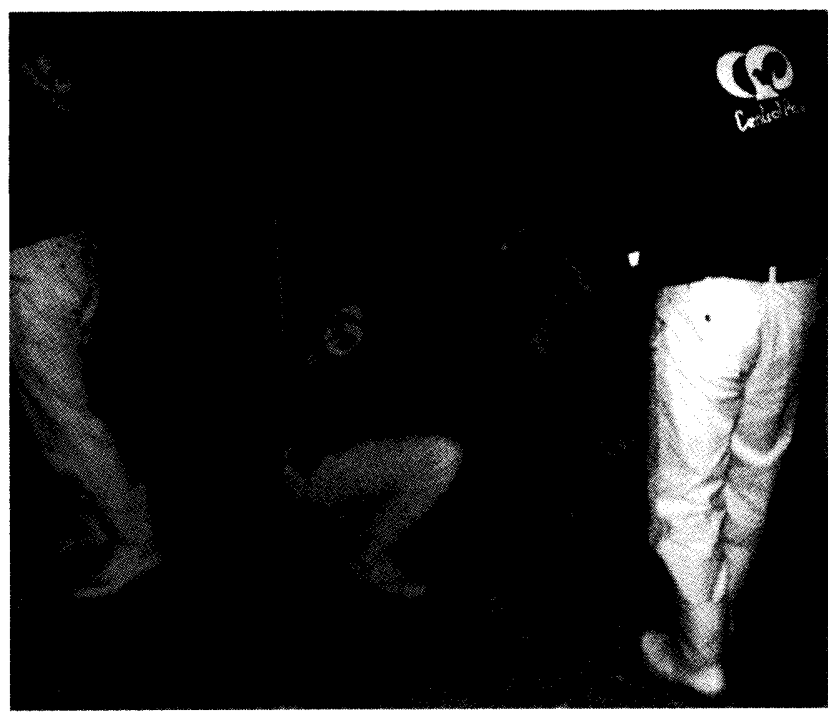

図3人工胵法によるバーラルからの精液採取風竪 (撮影場所：姫路セントラルパーク）

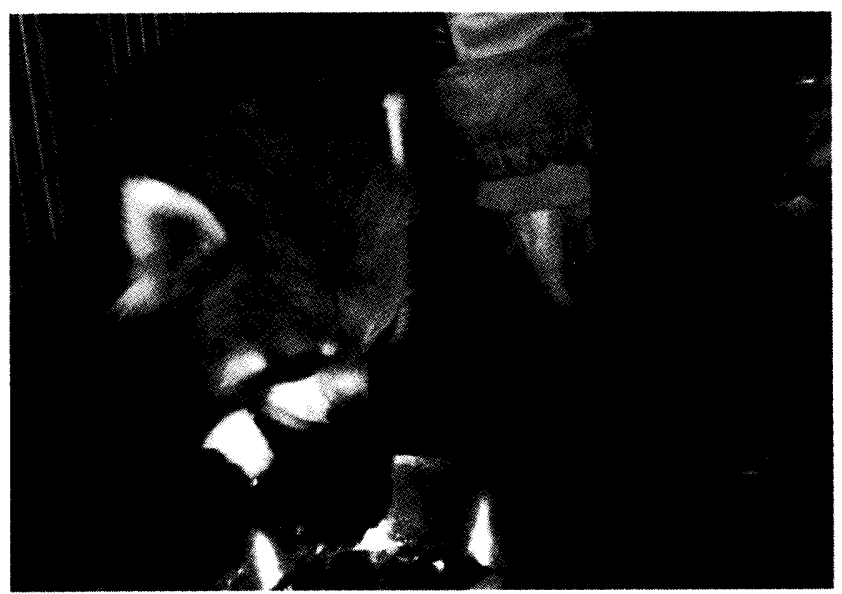

図4 陰茎マッサージ法によるレッサーパンダからの精液採取 風景（撮影場所：鯖江市西山動物園）

て, 繁殖期の雄の腹部を手指で押して, 輸精管内の精子を泌㽷 生殖突起から搾り出す方法（腹部厈搾法または搾出法）により， 比較的容易に精液が採取でき $[64,65]$, タナゴ $[66,67]$ （闵6) を含めた様々な希少魚類でも実施されている。腹部压㩁法によ る精液採取は，サンショウウオなどの両生類 [68］や各種の ヘビなどの爬虫類 [69］でも行われている。

しかし，家畜や家离などで常用されているこれらの方法で, 野生動物から精液が採取できるというのは，むしろ例外的な ケースであり，一般的には電気刺激を与えて射精を促す方法が 用いられる。この電気射精法は, Batelli [70]によってモルモ 
楠比呂志

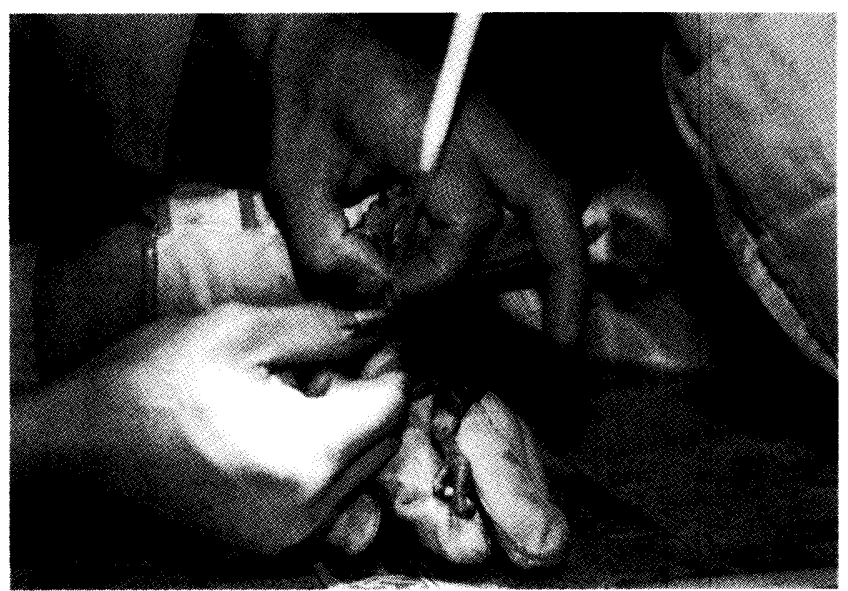

図 5 腹部マッサージ法によるゴシキセイガイインコからの精 液採取風景（撮影場所：姫路市立動物園）

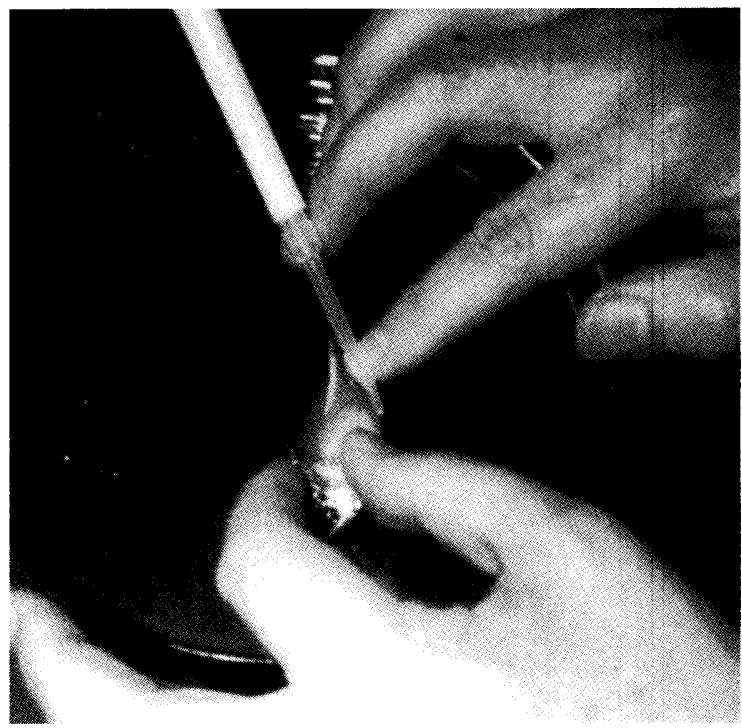

図6 腹部忹搾法によるニッポンバラタナゴからの精液採取風 景（撮影場所：神戸市立六甲アイランド高等学校）

ツトで考案された方法で，当初は頭部に通電していたが，その 後, 他の研究者により様々な改良が加えられ $[71,72]$, 最終 的に, Laplaud とCassou [73, 74] によって, 現在最も多用さ れている, 棒状の電極を直腸に挿入して通電する方法が完成し た。この経直腸電気射精法は，家畜では無麻酔下でも実施可能 であるが [75], 通常は麻酔下で実施する。経直腸法以外にも， クリップ式の電極を2 本用いてペニスに通電する方法（陰茎 法）もある [76]。この方法は, マカクなどの一部の霊長類で 用いられて抢り,こちらは無麻酔下で実施する。電気射精法は, 動物に構造上または機能的な欠陥がない限り，電極を工夫すれ

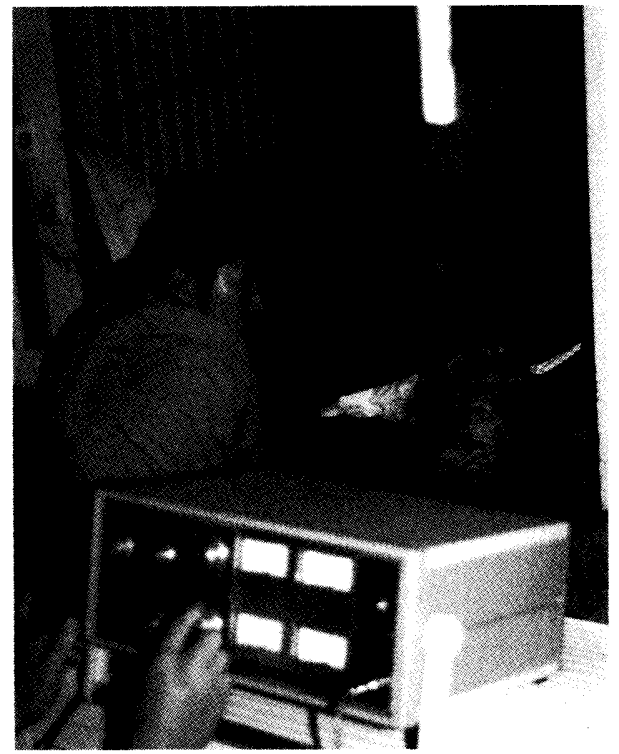

図7 経直腸電気射精法によるホッキョクグマからの精液採取 風景（撮影場所：アドベンチャーワールド）

ば, 理論的にはどの様な個体からでも精液の採取が可能であり， National Zoological Park では 90 種類以上の哺乳動物で [8], 筆者らもチーター [77] を始め 30 種類以上の哺乳動物で精液 採取を行っている（図 7)。哺乳類以外では，ウ二やイガイな どの海産無脊椎動物 [78], ツル [50] やタカ [57],アヒル [79] なぞの鳥類や,ウミガメ $[80,81]$ やリクガメ [82],へビ [83] などの爬虫類でも，電気射精法で精液が採取されている。

経済的な損失が大きいため, 生きた家畜ではほとんど行われ ることはないが，外科的に露出あるいは摘出した精巣上体や精 管を灌流したり [84]，精巣を細切して，精子を採取する方法 もある。

卵母細胞や胚（受精卵）の採取は，鳥類や爬虫類などの産卵 する卵生の動物では容易であるが, 細胞のサイズが巨大で, 卵 黄や多量の水分を含むなどの理由で，ウニ [85] やエビ [86] などの一部の無脊椎動物を除いて, 現在のところ,これらの凍 結保存は技術的に困難である。一方, 哺乳類などの胎生の動物 の場合は, 外科的に採取するしか手がない。すなわち, 開腹 して露出した卵管や子宮を灌流して肧を回収するか [87], 開 腹せずに腹腔鏡下で卵巣の卵胞から卵母細胞を吸引採取する [88]。腹腔鏡手術は, 高価な機器類と熟練した操作技術を必 要とするものの, 侵襲の少ない方法として, 動物園動物にも取 り入れられている $[89,90]$ (図 8)。なおウシでは, 経胵超音 波採卵法 [91］や子宮洗浄法 [92］により，非外科的に卵母 細胞や初期胚を採取することが可能である。 


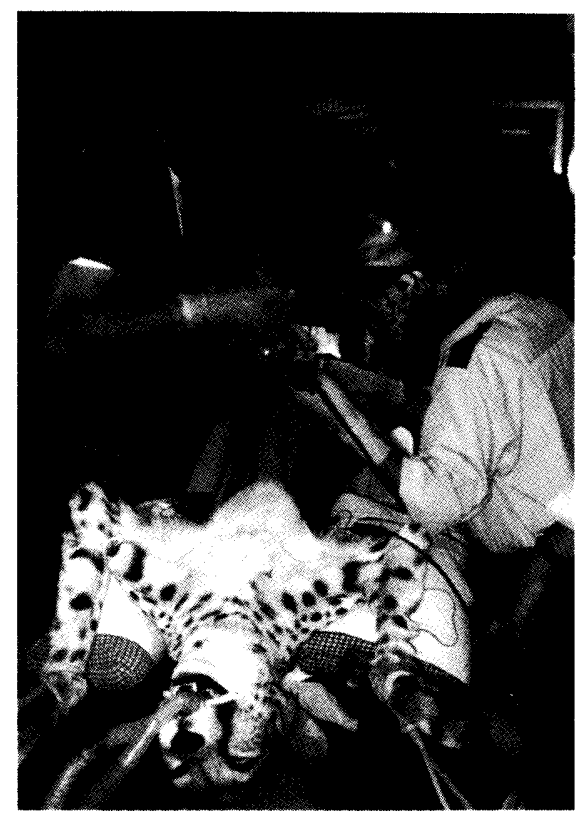

図8 腹腔鏡によるチーターの卵巣観察風景 （撮影場所：群馬サファリパーク）

\section{2. 死体からの回収}

現行の家畜の体外受精系で用いられる卵母細胞は, 通常, 屠場材料の卵巣の卵胞から卵核胞期の未成熟な一次卵母細胞を 採取し，体外で培養して成熟（減数分裂の完了を含む）させた のちに使用する $[93,94]$ 。また，射出精子（精液）の採取が 技術的に難しい上, 射精直後に精液が凝固するマウスなどの実 験小動物では, 雄を安楽死させた後に摘出した精巣上体から, 精子を圧出採取する方法が，日常的に用いられている [95]。 すなわち, 新鮮な死体から摘出した生殖器官からは, 生きた生 殖子を回収することが可能であり，ムフロン [96] とチンパ ンジー [97]（図 9）では, 死体から回収した精巣上体尾精子 を人工授精して産子が得られている。

哺乳動物の精子の受精能力は, 精巣で造られた後, 精巣上体 での成熟過程を経て，最終的には射精時に完備するといわれて いる [98］が, 筆者らが調べたところによれば, 潜在的な受 精能力, すなわち先体反応を起こして卵原形質膜と融合する能 力 [99] は, ブタでは精巣網に集められた時点で, ヤギでは 精巣上体頭遠位部に移送された辺りで獲得される [100-102]。 しかし, 前進運動能力は, やはり精巣上体尾部に達するまで獲 得されない。ニワトリでも精子の運動能力や受精能力は, 精巣 から精巣上体, 精管に移送されるにつれて上昇することが報告 されており [103]，サケやマスなどの魚類でも精巣や精管の 上部の精子は, 運動能力を持たないという [104]。したがって, 将来の授精方法に, 精子の運動性の有無を問わない後述の顕微

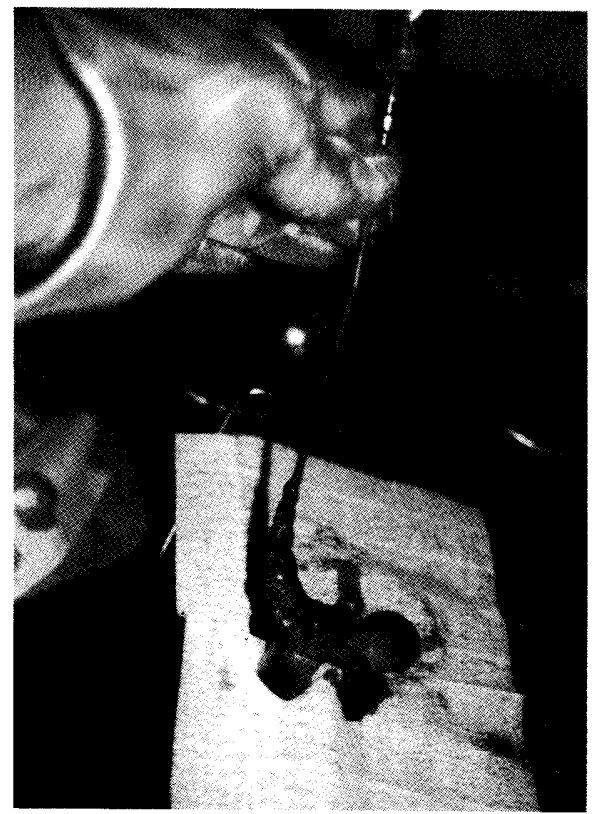

図9 灌流法による死亡したチンパンジーからの精巣上体精子 回収風景

授精法以前の方法, すなわち人工授精法や通常の体外受精法を 採用する予定であれば，雄性生殖道のなるべく下流から前進運 動している成熟精子を回収する必要がある。なお哺乳類では, 精巣上体尾が射精されるまでの精子の主要な貯蔵場所となって いるため,この部位からは多量の精子が回収できる。一方，爬 虫類や鳥類では, 精巣上体が未発達で尾に相当する部位もなく, 精子の貯蔵は主として精管で行われる。

この死体から回収する方法は, 特殊な器具や技能を特に必要 とせず，また動物への負担やストレスも全く心配する必要はな いが, 回収される生殖子は, 生体から採取されるものに比べて 概ね性状が悪い。特に卵母細胞や肧は, 精子よりも死後変化を 受けやすい上に，雄の遺伝情報と胚発生のきっかけを与える役 割を担う［105］にしかすぎない精子とは異なり，自身が分裂 を繰り返して個体にまで発生するので，わずかな傷害でも致命 的となる。また, 死因や年齢などによっては, 生殖子が全く回 収できないこともある。

死体からの配偶子の回収については, Johnston 5 [106] が, 北米の動物園で死亡したヒョウなどのネコ科動物の雌で実 施した報告があり，それによると回収率は 6 割程度で, 回収で きた卵母細胞も約 4 割が外見上不良であったという。筆者もこ れまでに爬虫類, 鳥類, 哺乳類あわせて 161 種 461 個体（雄 279 個体+雌 182 個体) の死体で回収を試み, 174 個体（雄 118 個体十雌 56 個体) では配偶子が回収できなかった（回収 率 62.3\% ）（表 1 ）。雄（56.6\%）（図 10）と雌（69.2\%）（図 



図 10 死亡したラッコから回収した精巣上体精子 (Wells-Awa 染色像 [149]，1,000 倍で撮影) 頭部前半の濃染部は先体で, 下の精子は先体の欠損異常が生じ ている。

11）では, 雌のほうが回収率は高かったが, 卵母細胞は胎生 期に形成が始まり, 生殖寿命が終わるまで常に卵巣に存在して いるので, かなりの老齢個体を除けば, 理論上, 雌からは常時 卵母細胞を回収することが可能である。一方，雄では，精子は 春機発動を迎えるまでは生産しておらず, 春機発動後も季節繁 殖動物では非繁殖期に精子を形成しないものも多い。したがっ て, 死亡の時期や年齢によっては, 精子がもともと存在しない こともある。なお, 季節繁殖動物でも, 栄養状態が常に充足し ている飼育下個体では, 野生下での非繁殖期にも精子を生産し ている場合もある。

性状が悪い配偶子でも，顕微授精や核移植などの最新技術を 用いれば, 産子の作出は不可能ではない。例えば, 精子の場合, 運動していなくとも形態が正常で生きたものが少数でも回収で きれば, 顕微授精法を適用する。顕微授精法は, 顕微鏡下で, マイクロマニピュレーターに取り付けた微細ガラスピペットを 用いて，1個の精子を卵細胞質内に注入する体外受精法で, 受 精現象の解明研究の目的で, ウニにおいて考案された [107]。

表 1 死体からの配偶子の回収成績 (1992.5.25 2005.1.31)

\begin{tabular}{|c|c|c|c|}
\hline 性別 & 供試個体数 & 配偶子回収個体数 & 回収率 (\%) \\
\hline 雄 & 279 & 161 & 56.6 \\
\hline 雌 & 182 & 126 & 69.2 \\
\hline 合計 & $461^{*}$ & $287^{* *}$ & 62.3 \\
\hline
\end{tabular}

*鳥類, 爬虫類, 哺乳類を含む 161 種

**生体から採取した分を加えて 338 個体（128 種）分 を保存

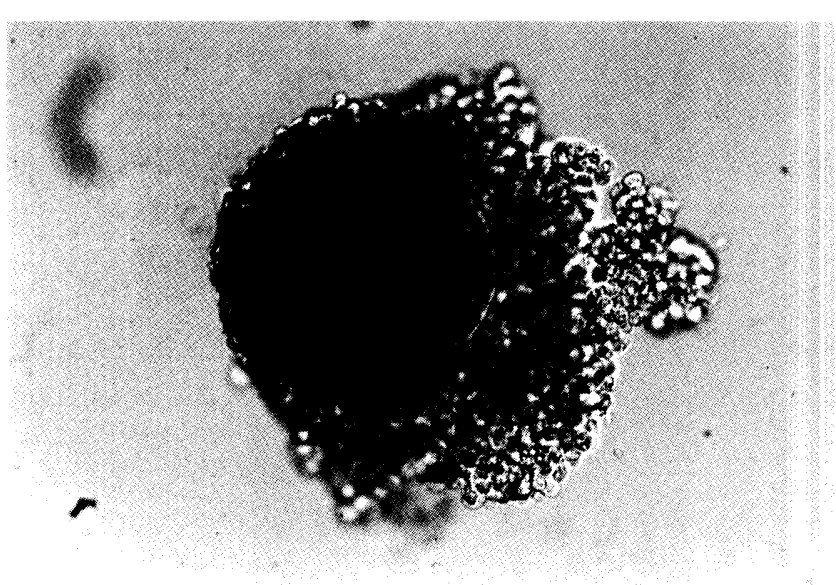

図 11 死亡したセスジキノボリカンガルーの卵巣の卵胞から 回収した卵母細胞（400 倍で撮影）

その後，哺乳類にも応用され [108]，Goto ら [109］が, ウ シで産子の作出に成功して以降，畜産分野のみならず，生殖医 療の分野でも一気に実用化が進み，今日では重度の男性不好症 の日常的な治療法となっている [110]。この方法による産子 の作出は，アカゲザルでも成功している [111]。一方、卵母 細胞の場合, 性状の悪いものからマイクロマニピュレーターを 用いて核を取り出し，除核した正常な別の卵母細胞に電気融合 法で移し替えてやる。ウシでは，この方法で，老化により性状 が劣化した卵母細胞から産子の作出に成功している [112]。

顕微授精を応用すれば，精子形成過程の途上にある精子細 胞やその前段階の精母細胞からでも産子が得られることが, マウスやマストミス，ウサギ，またヒトでも報告されている [113-117]。また，体外培養系 $[118,119]$ や同種または異種 の免疫不全動物の体内（精巣網や皮下） [120-123] で，精子 形成過程を再現することが，ウナギやメダカなどの魚類やイモ リやカエルなどの両生類, マウス, ラット, ブタ, ヤギ, ウシ およびアカゲザルなどの哺乳類で可能であり，筆者らも，共培 養条件下で, ヒトの一次精母細胞の減数分裂を完了させて精子 細胞に分化させたり [124], 精子細胞を精子に変態させるこ とに成功している [125]。したがって，精子形成が未完成の 若齢個体や，後天的な原因で途中で停止しているため，精子が 回収できない場合には，精子細胞や精母細胞などを採取して保 存するのも有効である。なお，これらの細胞は，分化した精子 とは異なり，体細胞と同様の方法で比較的簡単に保存できると いう [126]。

(社)日本動物園水族館協会 [127］によれば，2003 年度にわ が国の 87 施設の動物園と 61 施設の水族館で死亡した動物の 
数は, 雄雌併せて, 哺乳類が 4,055 個体, 鳥類が 2,974 個体, 両生類が 867 個体, 爬虫類が 778 個体の合計 8,674 個体と報 告されており,死体からの回収を全国レベルで組織的に行えば, かなりの種類と数の生殖子を収集することが可能である。なお, このうち寄生虫症と伝染病が原因で死亡した動物の数はそれぞ れ 129 個体 (1.5\%) と 85 個体 (1.0\%) で, かなり少ないも のの, 死体からの採材では, 感染症の危険性を常に念頭におい て, 細心の注意を払いながら実施しなければならない。注意す べき動物園動物や野生動物の感染症に関しては, 柳井ら [128] の報告を参照されたい。

未分化なものも含めて生殖子が全く回収できない場合には， 体細胞を採取することも考えられる。この場合, 個体の復元に は，クローン技術を用いることになる [1]。クローン動物の 作出は, 細胞の種類によって成功率には差があるものの, 入手 や保存が極めて容易な皮膚の細胞を始め様々な体細胞をドナ一 核として，これまでにカエル [129] と，ヒツジ，マウス，ウ シ, ブタ, ヤギ, ウサギ, ネコ, ウマおよびラットなどの哺乳 類 [130］で成功している。野生動物や動物園動物でも試みら れているが, 成功率がまだ低いこともあって，レシピエントの 卵母細胞には, 絶滅の心配がない近縁の異種動物のものが利用 されることが多く, これまでに, ヨーロッパムフロン, ボンゴ や野牛のバンテンとガウル, アルガリ，リビアヤマネコおよび ジャイアントパンダの体細胞核を, それぞれヒツジ, ウシ, ヤ ギ, イエネコおよびウサギの除核卵母細胞と融合させてハイブ リッドクローン胚が作出されており，ムフロンとバンテンおよ びガウルでは，これらの肧から外見上ノーマルな産子が得られ ている [131-136]。

我が国では, 1998 年に初の体細胞クローンウシが誕生し て以来 [137]，これまでにウシ，ブタおよびヤギでそれぞれ 425 頭, 81 頭および 5 頭のクローン家音が生まれているが [138], 現行の方法では, ゲノムDNAのメチル化に異常が生 じやすく, 流死産, 産後直死や形態形成異常などが高頻度で 発生することが報告されており [139]，これらを材料とした 畜産物が一般家庭の食卓に並ぶのは，まだかなり先の話と聞 く。こうしたクローンの技術上の問題点もさることながら、進 化の過程でより高等な生殖方法として有性生殖を獲得した動物 種で, 無性生殖を行うことの生物学上の是非や安全性について も，まだ十分に検討されておらず，これらの不安が完全に払拭 されない限り，この技術で作出された動物を野生復帰，すなわ ち「Living-free」とすることのコンセンサスを得るのは, 食品 としての流通解禁以上に難しいと思われる。したがって保全繁 殖技術では, 個体作出法を含めて, できる限りより自然に近い 方法を選択して使用するように努める必要がある。

保全繁殖技術を用いて希少動物を増殖させるには，本稿で紹
介したような生殖子を採取し取り扱う技術も重要であるが，対 象とする動物の繁殖生理, 特に雌の繁殖生理も十分に理解して おかねばならない。そのため筆者らは,アダックス [140] や ゾウ [141, 142], チーター [143] などで, 血中や糞中の性 ホルモンの動態や腟スメア像の変化などを調べ, これらの動物 の発情周期や妊娠生理なども解明しつつある。また, チーター ［144］やバーラル [36］では，発情（排卵）を人為的に誘起 する試みも行っている。

\section{おわりに}

保全繁殖技術の最終ゴールは，希少動物を液体窒素中で永久 保存したり, 生殖介助技術を駆使して動物園や水族館内で増や すことではない。緊急避難させた動物が本来の生息地に復帰し， 危機的な状況に二度と陥ることなく，ヒトと共生して行ける世 界を構築することであり，この目標を達成するには，生息地の 自然環境の悪化の阻止と回復, および永続的な維持も平行して 行ってゆかねばならない。

希少動物の種の保存を含めた環境保全の推進に当たっては, 爆発的な地球人口の増加が最大のネックとなる。U.S. Census Bureau の World POPClock Projection [145] では，世界人 口推定值をリアルタイムで開示しており，例えばグリニッジ 標準時 2005 年 1 月 30 日 22 時 7 分 17 秒現在の推定值は 6,415,777,639 人であった。United Nations Population Fund （UNFPA）が発表した最新の State of World Population Report 2004 [146] によれば，現在のペースで人口増が続くと，世 界人口は 2050 年に 89 億人に達するという。一方, 1.29 ショ ック［147］の我が国の場合，2050 年までに人口は約 1,800 万人減ると予想されている。このような地域差はあるものの, 地球レベルでタれば野生動物の存在を务かす人間の活動範囲 は依然狭まる気配はない。こうした状況の中, ロシアの批准に より, 採択から約 7 年を経て 2005 年 2 月に, Kyoto protocol [148］が発効し，国際的な温暖化防止対策がいよいよ本格始 動する。地球生態系を完全に再生させるには，相当な努力と年 月を要するであろうが，何としてでも完遂せねばならない。こ れは地球を污してきた我々人類の責務である。

\section{謝 辞}

本稿で紹介した研究成果は全て, 希少動物人工繁殖研究会会 員との共同研究によるものである。また，研究の一部は，神户 大学特定領域横断研究, 文部科学省科学研究費補助金基盤研究 C2（07660380），環境省環境試料タイムカプセル化事業，京 都大学霊長類研究所共同利用研究などの助成を受けて行われ た。 


\section{要 約}

地球規模での環境破壊により, 現在, 多くの野生動物が絶滅 の危機に立たされており，それらの種の保存は我々人類の急務 である。保全繁殖技術 (Reproductive Technologies for Species Conservation）とは, 希少動物の種の保存を目的とした繁殖技 術を指す。本稿では, 生息地外保全を補完する手段としての保 全繁殖技術の役割と重要性について論ずるとともに, その実際 として, 生殖子（配偶子や胚）の採取法 (人工胵法, マッサー ジ法, 電気射精法, 死後回収法など）について概説する。 キーワード : 生息地外保全, 人工繁殖, 精子, 卵母細胞, 胚

\section{引用文献}

1. Wilmut I, Schnieke AE, McWhir J, Kind AJ, Campbell KH. 1997. Viable offspring derived from fetal and adult mammalian cells. Nature 385 : 810-813.

2. [IUCN] 2003. 2003 IUCN Red List of Threatened Species. IUCN, Gland, Switzerland.

3. Raup DM. Stanley SM. 1978. Principles of Paleontology 2nd ed. W.H. Freeman, San Francisco, CA.

4. Thomas CD, Cameron A, Green RE, Bakkenes M, Beaumont LJ, Collingham YC, Erasmus BFN, Ferreira de Siqueira M, Grainger A, Hannah L, Hughes L, Huntley B, VanJaarsveld AS, Midgley GF, Miles L, Ortega-Huerta MA, Peterson AT, Phillips OL, Williams SE. 2004. Extinct risk from climate change. Nature 427: 145-148.

5. Secretariat of CBD/UNEP. 1992. Article 9. Exsitu Conservation. Convention on Biological Diversity. Secretariat of CBD, Quebec, Canada.

6. [IUDZG-WZO \& CBSG/IUCN/SSC] . 1993. The World Zoo Conservation Strategy. Chicago Zoological Society, Brookfield, Il.

7. [ISIS] 2005. ISIS: Fundamentals, http://www.isis.org/.

8. Wildt DE. 1997. Male Reproduction: Assessment, Management, and Control of Fertility. In Wild Mammals in Captivity, new ed (Kleiman DG et at. eds.) , pp. 429-450. Univ. of Chicago Press, Chicago.

9. 笹野聡美, 楠 比呂志, 福岡敏夫, 秋久成人, 八木智子, 林 恒弘. 2004 . 国内で飼育されていたニシローランドゴリラ（Gorila gorila gorila） 6 頭 における精巣の組織学的検査. 第 10 回日本野生動物医学会大会講演要旨 集.pp. 58.

10. Wiesner VH, Lampetr WW, Rietschel W. 1984. Experience from nonsurgical embryo transfer from banteng to domestic cattle. Int Symp Erkrank Zootiere Bmo Czechoslovakia. pp. 99-102.

11. Stover J, Evans J. 1984. Interspecies embryo transfer from gaur (Bos gaurus) to domestic holstein cattle (Bos taurus) at the New York Zoological Park. Proc 10th Int Congress of Anim Prod AI, Vol II. pp. 243-245.

12. Pope CE, Dresser BL, Kuehn G, Kramer L. Gillespite D. 1988. Live birth of a gaur (Bos gaurus) calf following nonsurgical embryo transfer to a Holstein (Bos taurus) recipient. Theriogenology 29: 289.

13. Pope CE, Gelwicks EJ, Wachs KB, Keller GL, Maruska EJ, Dresser BJ. 1989. Successful interspecies transfer of embryos from the Indian desert cat (Felis silvestris ornata) to the domestic cat (Felis catus) following in vitro fertilization. Biol Reprod 40 (S1) : 61.

14. Bunch TD, Foote WC. Whitaker B. 1977. Interspecies ovum transfer to propagate wild sheep. J Wildlife Manage 41: 726-730.

15. Flores-Foxworth G, Coonrod SA, Moreno JF, Byrd SR, Kraemer DC, Westhusin M. 1995. Interspecific transfer of IVM IVF-derived red sheep (Ovis orientalis gmelini) embryos to domestic sheep (Ovis aries). Theriogenology 44: 681-690.

16. Fernandez-Arias A, Folch J, Alabart JL, Ramon JP. 1996. Successful interspecific embryo transfer between Spanish lbex (Capra pyrenaica) and domestic goat (Capra hircus) using micro-osmotic pumps for FSH administration. Theriogenology 45: 247.

17. Bourke DA, Kyle CE, McEvoy TG, Young P, Adam CL. 1995. Superovulatory responses to eCG in llama (Lama glama). Theriogenology 44: 255-268.

18. Summers PM, Shephard AM, Hodges JK, Kydd J, Boyle MS, Allen WR. 1987. Successful transfer of the embryos of Przewalski's horses (Equus przewalskii) and Grant's zebra (E. burchelli) to domestic mares (E. caballus).J Reprod Fertil 80:13-20.

19. Pope CE. 2004. In vitro fertilization and embryo transfer in felids. Methods Mol Biol 254: 227-244

20. [CRES] 2005. Germplasm Preservation and Utilization. http://cres.sand iegozoo.org/projects/gr_germplasm.html.

21. Leeuwenhoek Av. 1678. Observationes de Anthonu Lewenhoeck, de natis e semine genitali animalculis. Phil Trans Roy Soc 12: 1040-1043.

22. Baccetti B, Afzelius BA. 1976. The Biology of the Sperm Cell. Monographs in Developmental Biology, Vol.10. S. Karger A.G., Basel.

23. Dunbar BS, O'Rand MG. 1991. A Comparative Overview of Mammalian Fertilization, Plenum Press, New York.

24. Watson PF. 1978. Artificial Breeding of Non-Domestic Animals, the Zoological Society of London, Academic Press, London.

25. Seager SWJ. 1983. The breeding of captive wild species by artificial methods. Zoo Biol 2: 235-239.

26. 楠田哲士. 2003. わが国の動物園における種の保存を目的とした希少動 物の繁殖研究と人工繁殖の現状. 動物園研究 7: 1-17.

27. Schimitt DL. 1998. Report of a successful artificial imsemination in an Asian elephant. Proc 3rd Int Elephant Res Symp. pp. 7.

28. Hildebrandt TB, Goitz F, Schnorrenberg A, Hermes R, Schmitt DL, Hagan D, Peterson JS, Brown JL, Loskutoff N, Pratt NC, Lehnhardt JL, Miller G, Montali RJ, Olson D. 1999. Successful artificial insemination of African nulliparous elephants at the Indianapolis Zoo. Verh ber Erkrg Zootiere 39: $41-46$.

29. 楠 比呂志. 2003. 温故知新（研究会の歴史, 沿革) . 希少動物人工繁殖研 究会研究報告集-十年の歩み（1993～2002 年）(希少動物人工繁殖研究 会編）,pp.2-3. 希少動物人工繁殖研究会，加西

30. Milovanov VK. 1938. Isskusstvenoye Ossemenebie Selsko-Khoziasvenny kh Jivotnykh. Seljhozgiz, Mowcow.

31. King GJ, Macpherson JW. 1973. A comparison of two methods for boar semen collection. J Anim Sci 36: 563-565.

32. Freiberg EA. 1935. Artificial insemination in the dog. Sluzebu Sokakovod $1: 4$. 


\section{保全繁殖技術}

33. Lambert WV, McKenzie FF, 1940. Artificial insemination in livestock breeding. Circ US Dep Agric 567.

34. Burrows WH, Quinn JP. 1935. A new method of obtaining spermatozoa from the domestic fowl. Poultry Sci 14: 251-254.

35. Miller FW, Evans EJ. 1934. Technique for obtaining spermatozoa for physiological dairy studies and artificial insemination. JAgr Res 48: 941 .

36. 上道幸史, 楠 比呂志. 2004. バーラルにおける人工授精の試み 2. 第 12 回希少動物人工繁殖研究会議要旨集. pp. 19.

37. Fussell EN, Franklin LW, Franta RC. 1973. Collection of chimpanzee sperm with an artificial vagina. Lab Anim Sci 23: 252-255

38. 洲鎌圭子, 松本清代恵, 楠比呂志, 森村成樹, 不破紅樹, 関根すみれな, 平田 聡, 伊谷原一. 2003. 人工䐋で採取したチンパンジー精子の凍結保 存.第 11 回希少動物人工繁殖研究会議要旨集.pp. 10.

39. Durrant BS, Millard SE, Zimmerman DM, Lindburg DG. 2001. Lifetime semen production in a cheetah (Acinonyx jubatus). Zoo Biol 20: 359-66.

40. Starkov ID. 1935. Artificial insemination in the fox. 1st All-Union Conf Artif Insem. pp. 122.

41. Seager SWJ. 1974. Semen collection and artificial insemination in captive wild cats. wolves and bears. PrC Am Acssoc Zoo Vet. pp. 29.

42. 中田 都. 2002. Project Lesser-Panda: 電気射精法およびマッサージ法に よる精液の採取、第 10 回希少動物人工繁殖研究会議要旨集. pp. 15.

43. Keller KV. 1986. Training of Atlantic bottlenose dolphins (Tursiops truncatus) for artificial insemination. 14th Ann IMATA Conf Proc. pp. 22-24.

44. Heath E, Jeyendran RS, Graham, EF. 1983. Ultrastructure of spermatozoa of the Asiantic elephant (Elephas maximus) , Zbl Vet $C$ Anat Histol Embryol 12: 245-252.

45. Price P, Bradford J, Schmitt D. 1986. Collection and semen analysis in Asian elephant. Proc Amer Assoc Zool Parks Aquar. pp. 310-313.

46. Durrant BS, Burch CD, Yamada JK, Good J. 1995. Seminal characteristics and artificial insemination of chinese pheasants, Tragopan temminckii, Lophophorus impeyanus and Lophophorus ihuysii. Zoo Biol 14: 523-531.

47. Saint Jalme M, Lecoq R, Seigneurin F, Blesbois E, Plouzeau E. 2003. Cryopreservation of semen from endangered pheasants: the first step towards a cryobank for endangered avian species. Theriogenology 59: 875-88.

48. 河野光彦. 1994. 鳥類の人工繁殖について（ウコッケイの仮母及び人工 授精）.第 2 回希少動物人工繁殖研究会議要旨集.pp. 4.

49. Mirande CM, Gee GF, Burke A, Whitlock P. 1996. CHAPTER 3. Egg and Semen Production. In Cranes: Their Biology, Husbandry and Conservation (Ellis DH, Gee GF, Mirande CM eds.) . pp. 45-58. US Department of Interior, National Biological Service, Washington, DC, International Crane Foundation, Baraboo, Wisconsin, and the US Fish and Wildlife Service, Washington, DC.

50. Gee GF, Mirande CM. 1996. CHAPTER 1 la. Special Techniques, Part A: Crane Artificial Insemination. In Cranes: Their Biology, Husbandry and Conservation (Ellis DH, Gee GF, Mirande CM eds.) . pp. 206-218. US Department of Interior, National Biological Service, Washington, DC, International Crane Foundation, Baraboo, Wisconsin, and the US Fish and Wildlife Service, Washington, DC.

51. Hargrove TL, Gee GF. 1996. CHAPTER 11 b. Special Techniques, Part
B: Cryopreservation. In Cranes: Their Biology, Husbandry and Conservation (Ellis DH, Gee GF, Mirande CM eds.) . pp. 219-222. US Department of Interior, National Biological Service, Washington, DC, International Crane Foundation, Baraboo, Wisconsin, and the US Fish and Wildlife Service, Washington, DC.

52. Brock MK. 1986. Cryopreservation of semen of the American Kestrel (Falco sparverius). MS Thesis, MacDonald Coll McGill Univ, Montreal, Canada.

53. Parks JE, Heck WR, Hardaswick Y. 1986. Cryopreservation of Peregrine Falcon semen and post-thaw dialysis to remove glycerol. Raptor Res 20: 16-20.

54. Gee GF, Morrell CA, Franson JC, Pattee OH. 1993. Cryopreservation of American Kestrel semen with dimethylsulfoxide. Raptor Res 27: 21-25.

55. Blanco JM, Gee G, Wildt DE, Donoghue AM. 2000. Species variation in osmotic, cryoprotectant, and cooling rate tolerance in poultry, eagle, and peregrine falcon spermatozoa. Biol Reprod 63: 1164-1171.

56. Blanco JM, Gee GF, Wildt DE, Donoghue AM. 2002. Producing progeny from endangered birds of prey: Treatment of urine-contaminated semen and a novel intramagnal insemination approach. J Zoo Wildl Med 33: 1-7.

57. Fox N. 1995. Understanding the Bird of Prey. Hancock House Pub Ltd, Surrey B.C.

58. Gee GF, Sexton TJ. 1990. Cryogenic preservation of semen from the Aleutian Canada Goose. Zoo Biol 9: 361-371.

59. Hargrove TL. 1986. Cryogenic preservation of Budgerigar (Melopsittacus undulatas) semen. MS Thesis, Florida Atlantic Univ, Boca Raton.

60. Samour JH, Smith CA, Moore HDM, Markham JA. 1986. Semen collection and spermatozoa characteristics in budgerigars (Melopsittacus undulatus). Vet Rec 118: 397-399.

61. Samour JH, Markham JA, Moore HDM. 1988. Semen cryopreservation and artificial insemination in Budgerigars (Melopsittacus undulatus) . $J$ Zool (Lond) 216: 169-176.

62. Von Rautenfeld DB. 1977. Mitteilungen zur kunstlichen Besamung,Geschlechts- und Altersbestimmung beim Strauss (Struthio camelus australis, GURNEY). Prakt Tierarzt 58: 359-364.

63. Robinson M. 1999. Goshawk semen shipping and handling. In Captive Propagation of the Northern Goshawk. Dr. Meg Robinson, Waterford. WI.

64. 黒倉寿. 1983. 一綜説一魚類精液の凍結保存. 水座育種 8: 42-53.

65. 社日本水産資源保護協会. 1999. 精子の凍結保存. 水産生物の遺伝的多柈 性の評価及び保存に関する技術マニュアル，pp. 163-192. 水産庁委託 漁業 新技術開発試験事業平成 $6 \sim 10$ 年度総合報告書

66. 岩本哲人, 藤本雅実, 千木良裕美, 楠 比呂志. 2000 . 絶滅危惧種である 淡水魚タナコ類の凍結精子を用いた人工繁殖に関する研究．第 8 回希少 動物人工繁殖研究会議要旨集. pp. 9-10.

67. 仲尾有加. 2000. 野毛山動物園におけるミヤコタナゴの人工授精につい て.第8回希少動物人工繁殖研究会議要旨集.pp.11.

68. 金立成，汪建國。1997, 精液離體保存.大鯢的生物学興養殖實用技術. 120-126.

69. Mengden GA, Platz CG, Hubbard R, Quinn H. 1980. Semen collection, freezing and artificial insemination in snake. In Reproductive Biology and Diseases of Captive Reptiles (Murphy JB, Collins JT eds.) . pp. 71-79. Lawrence, KS.

70. Batelli F. 1922. Une methode pour obtenir l'emission complete du 
liquid des vesicules seminales chez cobaye. Cr Soc Phys hist Nat Geneve 39: 73-74.

71. Moore CR, Gallagher TF. 1930. Seminal vesicle and prostatic function as a testis-hormone indicator: the electricejaculation test. Am J Anat 45: 39-69.

72. Gunn RMC. 1936. Fertility in sheep. Artificial production of seminal ejaculation and the characters of the spermatozoa contained therein. Bull Coun scient ind Res Melb 94: 1-116.

73. Laplaud M, Cassou R. 1945. Nouveau procede de recolte du sperme par electrode bipolaire rectale unique. Cr Acad agric Fr 31:37.

74. Laplaud M, Cassou R. 1948. Recherches sur l'electro-ejaculation chez le taureau et le verrat. Cr Seance Soc Biol 142: 726-727.

75. Martin ICA, Rees D. 1962. The use of direct current pulses for the electroejaculation of the bull. Aust vet $J$ 38: 92-98.

76. Mastroianni LJr, Manson WAJr. 1963. Collection of monkey semen by electroejaculation. Proc Soc Exp Biol Med 112: 1025-1027.

77. 楠 比呂志. 1996. チーターの繁殖生理と人工繁殖，遺伝 50: 24-29.

78. 久米又三, 団勝磨. 1957. 無奉椎動物発生学. 培風館. 東京.

79. 渡辺守之. 1958. あひるの人工授精に関する研究, III. 電気刺激による精 液採取について, 家畜繁殖誌 3: 103

80. Wood F, Platz C, Critchley K, Wood J. 1982. Semen collection by electroejaculation of the Green Turtles, Chelonia mydas. Brit J Herpetol 6: 200-202.

81. 大池辰也, 黒柳賢治, 楠 比呂志, 亀崎直樹. 2002. ウミガメの人工繁殖 に向けての基礎的研究. 第 10 回希少動物人工繁殖研究会議要旨集.pp. 12.

82. 川上博司 . 2002. インドホシガメの人工繁殖プロジェクト（採精の試み） 経過報告.第10回希少動物人工繁殖研究会議要旨集.pp. 13-14.

83. Quinn H, Blasedel T, Platz CCJr. 1989. Successful artificial insemination in the checkered garter snake. Int Zoo Yb 28: 177-183.

84. Czarnotzky EJ, Henle W. 1938. A pressure device for the separation of mammalian spermatozoa from the isolated epididymis. Proc Soc Exp Biol 38: 36

85. Asahina E, Takahashi T. 1979. Cryopreservation of sea urchin embryos and sperm. Dev Growth Differ 21: 423-430.

86. 社)日本水産資源保護協会. 1999. 卵母細胞の凍結保存（クルマエ ビ）.水産生物の遺伝的多様性の評価及び保存に関する技術マニュアル，pp. 192-196. 水産庁委託 漁業新技術開発試験事業平成 $6 \sim 10$ 年度総合報 告書.

87. Dzuik PJ. 1971. Obtaining eggs and embryos from sheep and pigs. In Methods in Mammalian Embryology (Daniel JCJr ed.). W.H. Freeman. San Francisco, CA.

88. Snyder DA, Dukelow WR. 1974. Laparoscopic studies of ovulation, pregnancy diagnosis, and follicle aspiration in sheep. Theriogenology 2 : 143-148

89. Bush M, Seager SWJ, Wildt DE. 1980. Laparoscopy in Zoo Mammals, In Animal Laparoscopy (Harrison RM, Wildt DE eds) , pp. 169-182. Williams \& Wilkins, Baltimore/London.

90. 川上茂久. 2003. 腹腔鏡の野生動物への適応. 希少動物人工繁殖研究会 研究報告集一十年の歩み（1993～2002 年）（希少動物人工繁殖研究会 編），pp.158-160. 希少動物人工繁殖研究会，加西
91. Wikland M, Enk L, Hamberger L. 1985. Transvesical and transvaginal approaches for the aspiration of follicles by the use of ultrasound. Ann NY Acad Sci 442: 683-689.

92. Rowson LEA, Dowling DW, 1949. An apparatus for the extraction of fertilised eggs from the living cow. Vet Rec 61: 191.

93. Iritani A. Niwa K. 1977. Capacitation of bull spermatozoa and fertilization in vitro of cattle follicular oocytes matured in culture. J Reprod Fertil 50: 119-121

94. Iritani A, Niwa K, Imai H. 1978. Sperm penetration in vitro of pig follicular oocytes matured in culture. J Reprod Fertil 54: 379-383.

95. Yanagimachi R, Chang MC. 1963. Fertilization of hamster eggs in vitro. Nature Lond 200: 281-282.

96. Garde J. Perez S, Aguado MJ, Ayllon E, Garrido D, Montoro V. 1995. Live birth of hybrid ( $O$. musimon $\mathrm{x} O$. aries) lambs following intrauterine insemination in domestic sheep with mouflon semen obtained 40 hours postmortem. Theriogenology 43: 218.

97. Kusunoki H, Daimaru H, Minami S, Nishimoto S, Yamane K, Fukumoto Y. 2001. Birth of a chimpanzee (Pan troglodytes) after artificial insemination with cryopreserved epididymal spermatozoa collected postmortem. Zoo Biol 20: 135-143.

98. Amann RP, Hammerstedt RH, Veeramachaneni DNR. 1993. The epididymis and sperm maturation: A perspective. Reprod Fertil Dev 5 361-381.

99. 楠比呂志. 1993. 家畜精子の先体反応，日音関西支部報 123:12-15.

100. Harayama H, Kusunoki H, Kato S. 1993. Motility and penetrability into zona-free hamster eggs of boar spermatozoa collected from various regions of the epididymis. J Reprod Dev 39:41-45.

101. Harayama H, Kusunoki H, Kato S. 1993. Capacity of rete testicular and cauda epididymal boar spermatozoa to undergo the acrosome reaction and subsequent fusion with egg plasma membrane. Mol Reprod Dev 35: $62-68$

102.Harayama H, Kusunoki H, Kato S. 1993. Capacity of goat epididymal spermatozoa to undergo the acrosome reaction and subsequent fusion with egg plasma membrane. Reprod Fertil Dev 5: 239-246.

103.Murno SS. 1938. Functional changes in fowl sperm during their passage through the excurrent ducts of the male. J Exp Zool 79: 71-92.

104.Morisawa S, Morisawa M. 1986. Acquisition of potential for sperm motility in rainbow trout and chum salmon. J Exp Biol 126: 89-96.

105.Swann K. 1990. A cytosolic sperm factor stimulates repetitive calcium increase and mimic fertilization in hamster eggs. Development 110 : 1295-1302

106.Johnston LA, Donoghue AM, O'Brien SJ, Wildt DE. 1991. Rescue and maturation in vitro of follicular oocytes collected from nondomestic felid species. Biol Reprod 45: 898-906.

107. Hiramoto Y. 1962. Microinjecton of the live spermatozoa into sea urchin eggs. Exp Cell Res 27: 416-426.

108.Uehara T, Yanagimachi R. 1976. Microsurgical injection of spermatozoa into hamster eggs with subsequent transformation of sperm nuclei into male pronuclei. Biol Reprod 15: 467-470

109.Goto K, Kinoshita A, Takuma Y, Ogawa K. 1990. Fertilisation of bovine oocytes by the injection of immobilised, killed spermatozoa. Vet Rec 


\section{保全繁殖技術}

127: $517-520$

110. 粟田松一郎, 田中温, 永吉 基, 馬渡善文, 田中威づみ, 竹本洋一, 高崎 博幸, 井手紀子, 有本恭子, 岩本智子, 楠 比呂志. 1996. 顕微授精とそ の実際，産婦人科治療 72: 912-920

111. Hewitson L, Dominko T, Takahashi D, Martinovich C, Ramalho-Santos J, Sutovsky P, Fanton J, Jacob D, Monteith D, Neuringer M, Battaglia D, Simerly C, Schatten G. 1999. Unique checkpoints during the first cell cycle of fertilization after intracytoplasmic sperm injection in rhesus monkeys. Nat Med 5: 431-433.

112. 桑山正成，水野仁二，寺元章吉，加藤修．2001。除核ドナー卵子への GV 移植による老化卵子の発生能改善効果. 不妊学会誌 46: 397.

113.Sofikitis NV, Miyagawa I, Agapitos E, Pasyianos P, Toda T, Hellstrom WJ, Kawamura H. 1994. Reproductive capacity of the nucleus of the male gamete after completion of meiosis. J Assist Reprod Genet 11 : 335-341.

114.Tesarik J, Mendoza C, Testart J. 1995. Viable embryos from injection of round spermatids into oocytes. NEngl J Med 333: 525

115.Kimura Y, Yanagimachi R.1995. Development of normal mice from oocytes injected with secondary spermatocyte nuclei. Biol Reprod 53: 855-862.

116. Kimura Y, Tateno H, Handel MA, Yanagimachi R. 1998. Factors affecting meiotic and developmental competence of primary spermatocyte nuclei injected into mouse oocytes. Biol Reprod 59: 871-877.

117.Ogonuki N, Mochida K, Inoue K, Matsuda J, Yamamoto Y, Takano K, Ogura A. 2003. Fertilization of oocytes and birth of normal pups following intracytoplasmic injection with spermatids in mastomys (Praomys coucha). Biol Reprod 68: 1821-1827.

118. Nishimune Y, Aizawa S, Komatsu T. 1978. Testicular germ cell differentiation in vitro. Fertil Steril 29: 95-102.

119. 安部眞一. 1992. 第 3 章 精子形成 3.2 培養による精子形成. 精子学 (毛 利秀雄監修, 森沢正昭, 星 元紀編），pp. 54-67. 東京大学出版会, 東京.

120. Clouthier DE, Avarbock MR, Maika SD, Hammer RE, Brinster RL. 1996 Rat spermatogenesis in mouse testis. Nature 381: 418-21.

121. Honaramooz A, Snedaker A, Boiani M, Scholer H, Dobrinski I, Schlatt S 2002. Sperm from neonatal mammalian testes grafted in mice. Nature 418: 778-781.

122.Honaramooz A, Li MW, Penedo MC, Meyers S, Dobrinski I. 2004. Accelerated maturation of primate testis by xenografting into mice. Biol Reprod 70: 1500-1503.

123.Izadyar F, Den Ouden K. Stout TA, Stout J, Coret J, Lankveld DP, Spoormakers TJ, Colenbrander B, Oldenbroek JK, Van der Ploeg KD, Woelders H, Kal HB, De Rooij DG. 2003. Autologous and homologous transplantation of bovine spermatogonial stem cells. Reproduction 126 : 765-774.

124.Tanaka A, Nagayoshi M, Awata S, Mawatari Y, Tanaka I, Kusunoki H. 2003. Completion of meiosis in human primary spermatocytes through in vitro coculture with Vero cells. Fertil Steril 79: 795-801.

125.Tanaka A, Tanaka I, Nagayoshi M, Awata S, Mawatari Y, Kusunoki H. 2000. Flagella-formating potency of cultured round spermatids (R-ST) . Proc 56th Annual Meet Am Soc Reprod Med S126.
126.Ogura A, Matsuda J, Asano T, Suzuki O, Yanagimachi R. 1996. Mouse oocytes injected with cryopreserved round spermatids can develop into normal offspring. J Assist Reprod Genet 13: 431-434.

127. 社)日本動物園水族館協会. 2004. 原因別死亡動物調.日動水年報平成 15 年度: $131-147$.

128. 柳井徳麿, 杉山誠, 平田晆大, 酒井洋樹, 柵木利昭, 吉川泰弘. 2003. 動物園動物および野生動物の感染症. 野生動物医誌 8: 1-10.

129.Gurdon JB. 1962. The developmental capacity of nuclei taken from intestinal epithlium cells of feeding tadpoles. J Embryol Exp Morphol 10: 622-640.

130. 角田幸雄, 加藤容子. 2004. クローン動物の発生のしくみと寿命. 遺伝 58: 64-68.

131.Loi P, Ptak G, Barboni B, Fulka JJr, Cappai P, Clinton M. 2001. Genetic rescue of an endangered mammal by cross-species nuclear transfer using post-mortem somatic cells. Nat Biotechnol 19: 962-964.

132.Lanza RP, Cibelli JB, Diaz F, Moraes CT, Farin PW, Farin CE, Hammer CJ, West MD, Damiani P. 2000. Cloning of an endangered species (Bos gaurus) using Interspecies nuclear transfer. Cloning 2: 79-90.

133.Lee B, Writ GG, Damiani P, Pope CE, Dresser BL, Hwang W, Bavister BD. 2003. Blastocyst development after intergeneric nuclear transfer of mountain bongo antelope somatic cells into bovine oocytes. Cloning Stem Cells 5: 25-33.

134.White KL, Bunch TD, Mitalipov S, Reed WA. 1999. Establishment of pregnancy after the transfer of nuclear transfer embryos produced from the fusion of argali (Ovis ammon) nuclei into domestic sheep (Ovis aries) enucleated oocytes. Cloning 1: 47-54.

135.Gomez MC, Jenkins JA, Giraldo A, Harris RF, King A, Dresser BL, Pope CE. 2003. Nuclear transfer of synchronized african wild cat somatic cells into enucleated domestic cat oocytes. Biol Reprod 69: 1032-1041.

136.Chen DY, Sun QY, Liu JL, Li GP, Lian L, Wang MK, Han ZM, Song XF, Li JS, Sun Q, Chen YC, Zhang YP, Ding B. 1999. The giant panda Aluropoda melanoleuca somatic nucleus can dedifferentiate in rabbit ooplasm and support early development of the reconstructed egg. Sci China (Series C) 29: $324-330$

137.Kato Y, Tani T, Sotomaru Y, Kurokawa K, Kato J, Doguchi H, Yasue H, Tsunoda Y. 1998. Eight calves cloned from somatic cells of a single adult. Science 282: 2095-2098.

138. 農林水産技術技術会議事務局. 2004. 家畜クローン研究の現状につい て.http://www.s.affrc.go.jp/docs/press/2004/1118b.htm.

139. Ohgane J, Wakayama T, Kogo Y, Senda S, Hattori N, Tanaka S, Yanagimachi R, Shiota K. 2001. DNA methylation variation in cloned mice. Genesis 30: 45-50.

140. 楠田哲士，長神大忠，西角知也，中川大輔，上田か子る，大江智子，奥 田和男, 楠 比吕志, 土井 守.2004.アダックスの発情周期や繁殖行動 に伴う性ステロイドホルモン濃度の動態と妊娠診断について. 第 10 回 日本野生動物医学会大会講演要旨集. pp. 39.

141.Doi O, Komatsumoto M, Terazono M, Wada S, Akihisa N, Sakamoto H, Hamasaki T, Yanagimoto H, Nakano K, Matsuoka K, Ito A, Kusunoki H, Nakamura T. 2000. Exfoliative cytology in Vaginal Vestibule of female asian elephants: Relation to circulating progesterone concentrations. Zool Sci 17: 1303-1309. 


\section{楠 比呂志}

142. 土井 守, 山田朋美, 寺園美奈子, 和田晴太郎, 秋久成人, 坂本英房, 濱 崎勉, 柳本 博, 中野和彦, 松岡賢司, 伊藤 淳, 岩橋宣明, 水野章裕, 楠 比呂志. 2001. 雌アジアゾウにおける発情周期中の䏬前庭粘膜面の肉 眼的変化.野生動物医誌 6: 55-59.

143.Doi O, Shibayama N, Sugiura K, Kusunoki H, Sato T, Tomita T, Abe T, Fukushige S, Sakata M, Sasaki Y, Nishikaku T, Tasaki Y, Hase T, Nakamura T. 1995. Changes in plasma concentrations of progesterone and estradiol- $17 \beta$ in non-pregnant and pregnant cheetahs (Acinonyx jubatus) .J Reprod Dev 4 1: 235-239.

144.Doi O, Kusunoki H, Sato T, Kawakami S, Fukuoka T, Okuda K, Ito S, Saito E, Hayashi T, Hase T, Kamiyoshi M. 2001. Serum progesterone and estradiol-17 $\beta$ concentrations, and laparoscopic observations of the ovary in the Cheetah (Acinonyx jubatus) with pregnant mare serum gonadotropin and human chorionic gonadotropin treatments. J Vet Med
Sci 63: 1361-1364

145.U.S. Census Bureau. 2005. World POPClock Projection. http://www.cen sus.gov/cgi-bin/ipc/popclockw.

146. [UNFPA] 2004. State of World Population Report 2004. UNFPA, New York. NY.

147. 厚生労㗢省大臣官房統計情報部. 2004. 平成 15 年人口動態統計月報 年計（概数）の概況. http://www.mhlw.go.jp/toukei/saikin/hw/jinkou /geppo/nengai03/brth.html\#2-2.

148. [UNFCCC] 1997. Kyoto protocol. http://unfccc.int/essential_backgro und/kyoto_protocol/items/1678.php.

149. Wells ME, Awa OA. 1970. New technique for assessing acrosomal characteristics of spermatozoa. J Dairy Sci 53: 227-232. 